\title{
Modulation of MMP-2 and MMP-9 by cytokines, mitogens and inhibitors in lung cancer and malignant mesothelioma cell lines
}

\author{
M. WAHEED ROOMI, JULIO C. MONTERREY, TATIANA KALINOVSKY, \\ ALEKSANDRA NIEDZWIECKI and MATTHIAS RATH
}

Dr. Rath Research Institute, 1260 Memorex Drive, Santa Clara, CA 95050, USA

Received June 25, 2009; Accepted September 4, 2009

DOI: 10.3892/or_00000566

\begin{abstract}
Matrix metalloproteinases (MMPs) secreted by lung cancer (LC) and malignant mesothelioma (MM), especially MMP-2 and MMP-9, play crucial roles in tumor invasion and metastasis. We examined the effect of cytokines, mitogens and inhibitors on MMP-2 and MMP-9 expression in LC and MM cell lines. Human LC (A-549) and MM (MSTO-211H) cell lines were cultured in appropriate media. At near confluence, the cells were washed with PBS and incubated in serum-free medium with various concentrations of several cytokines, mitogens and inhibitors. After $24 \mathrm{~h}$ the media were removed and analyzed for MMP-2 and MMP-9 by gelatinase zymography and quantitated by densitometry. LC expressed MMP-2 whereas MM expressed MMP-2 and MMP-9. TNF- $\alpha$, IL-1 1 , LPS and PMA, stimulated MMP-2 in LC and inhibited MMP-2 in MM, but had no effect on MMP-9. Doxycycline, EGCG and NM inhibited MMP-2 and MMP-9 expression, in both cell lines. Actinomycin-D, cyclohexamide, retinoic acid and dexamethasone inhibited MMP-2 in both cancer cell lines and inhibited MMP-9 in MM. Our results show that cytokines and inhibitors have an up- or downregulatory effect on MMP-2 and MMP-9 expression in LC and $\mathrm{MM}$, suggesting the clinical value of targeting these proteases for management of LC and MM and their pathogenesis.
\end{abstract}

\section{Introduction}

Lung cancer (LC), the most common cause of cancer death in men and women is associated with tobacco smoking and exposure to radon and asbestos. In 2005, 107,416 men and 89,271 women were diagnosed with, and 90,139 men and 69,078 women died from lung cancer in the USA (1). The incidence is decreasing slightly in men but rising sharply in

Correspondence to: Dr Aleksandra Niedzwiecki, Dr. Rath Research Institute, 1260 Memorex Drive, Santa Clara, CA 95050, USA

E-mail: author@drrath.com

Key words: lung cancer, mesothelioma, MMP-2, MMP-9, cytokines, mitogens, inhibitors women. The median age at diagnosis is approximately 70 years. Malignant mesothelioma (MM), a rare highly aggressive tumor with no known cure, is associated with asbestos exposure. MM is characterized by aggressive local growth, invasion of vital mediastinal structures and death within 418 months. Metastasis has been documented in $50 \%$ of patients $(2,3)$. Metastasis, a complex multi-step process, includes detachment of cancer cells from the primary tumor, disruption of the basement membrane and subsequent invasion into surrounding stroma, the vascular or lymphatic system and transport to distal sites (4). Substantial evidence links MMP expression to tumor invasion in many different tumors (5-10). In addition, clinical studies note the association of matrix metalloproteinase (MMP) expression with progression of malignant mesothelioma $(11,12)$ and lung cancer $(13,14)$.

Matrix metalloproteinases (MMPs) are a family of zincdependent proteolytic enzymes that degrade various components of the extracellular matrix (ECM), including collagen, laminin, fibronectin, vitronectin, elastin and proteoglycans and are considered critical to cancer invasion, migration, metastasis and tumorigenesis $(5,6,15)$. Blocking tumor cell expression of MMPs can significantly reduce tumor invasion and metastasis. Although all five major classes of proteases (serine, threonine, cysteine, aspartic acid and metalloproteases) are involved in invasion and metastasis, attention has been focused on type IV collagenases, MMP-2 and MMP-9, also known as gelatinase $\mathrm{A}$ and $\mathrm{B}$, both of which cleave collagen type IV, a major component of ECM and basement membrane. MMP-2 (72 kDa) and MMP-9 (92 kDa) are secreted in their latent zymogenic form and cleaved by other MMPs or proteases to yield the activated forms of 68,58 and $54 \mathrm{kDa}$ for MMP-2 and $94 \mathrm{kDa}$ for MMP-9. Increased expression of MMP-2 and MMP-9 are reported in many human tumors, including ovarian, breast and prostate tumors and melanoma (16-18). A significant correlation has been reported between tumor aggression and increased levels of MMP-2 and MMP-9 in many experimental and clinical studies (5-10).

MMP activity is regulated and dependent on environmental influences from surrounding stroma, ECM protein, systemic hormones and other factors $(17,19,20)$. MMP activity is also controlled by a variety of cytokines and growth factors such as transforming growth factor (TGF- $\beta$ ), hepatocyte growth factor (HGF), epidermal growth factor (EGG) and tumor necrosis factor- $\alpha(\mathrm{TNF}-\alpha)(21,22)$. One of the most potent inducers is the chemical agent phorbol 12-myristate 13-acetate 
(PMA). In addition, activity of MMPs is regulated at multiple levels, including transcription, modulation of messenger RNA half-life (translation), secretion, localization, activation and inhibition (23).

In this study, we investigated the effects of cytokines, mitogens and inhibitors in the regulation of MMP-2 and MMP-9 activities in two related cancer cell lines, lung cancer (LC) and malignant mesothelioma (MM).

\section{Materials and methods}

Materials. Human LC (A-549) and MM (MSTO-211H) and culture media Ham F-12 and RPMI were purchased from ATCC. Antibiotics, penicillin and fetal bovine serum (FBS), were obtained from Gibco (BRL, Long Island, NY). Twentyfour well tissue culture plates were obtained from Costar (Cambrdige, MA). Gelatinase zymography was performed in $10 \%$ Novex pre-cast SDS polyacrylamide gel (Invitrogen, Inc.) with $0.1 \%$ gelatin in non-reducing conditions. Interleukin $1 \beta$ (IL-1ß), tumor necrosis factor- $\alpha$ (TNF- $\alpha)$, PMA, liposarcoma (LPS), doxycycline, epigallocatechin gallate (EGCG), cyclohexamide, actinomycin-D, retinoic acid and dexamethasone, were purchased from Sigma (St. Louis, MO). The nutrient mixture (NM), prepared by VitaTech (Hayward, CA) was composed of the following ingredients in the relative amounts indicated: vitamin $\mathrm{C}$ (as ascorbic acid and as $\mathrm{Mg}$, $\mathrm{Ca}$ and palmitate ascorbate), $700 \mathrm{mg}$; L-lysine 1,000 mg; L-proline, $750 \mathrm{mg}$; L-arginine, $500 \mathrm{mg}$; N-acetyl cysteine, $200 \mathrm{mg}$; standardized green tea extract ( $80 \%$ polyphenol), $1,000 \mathrm{mg}$; selenium, $30 \mu \mathrm{g}$; copper, $2 \mathrm{mg}$; manganese, $1 \mathrm{mg}$. All other reagents used were of high quality and were obtained from Sigma, unless otherwise indicated.

Cell cultures. The LC (A-549) and MM (MSTO-211H) cell lines were grown in Ham F-12 and RPMI media supplemented with $10 \%$ FBS, penicillin (100 units $/ \mathrm{ml})$ and streptomycin $(100 \mu \mathrm{g} / \mathrm{ml})$ in 24 -well tissue culture plates. The cells were plated at a density of $1 \times 10^{5}$ cells $/ \mathrm{ml}$ and maintained in a humidified atmosphere of $5 \% \mathrm{CO}_{2}$ in air at $37^{\circ} \mathrm{C}$ until confluent. Serum-supplemented medium was removed and cell monolayer was washed twice with PBS, and once with serumfree media. The cells were then incubated in $0.5 \mathrm{ml}$ of serumfree medium with various cytokines, mitogens, and inhibitors in triplicates: PMA $(10,25,50,100 \mathrm{ng} / \mathrm{ml})$; TNF- $\alpha(0.1,1$, $10,25 \mathrm{ng} / \mathrm{ml}) ; \mathrm{IL}-ß(0.1,1,10,25 \mathrm{ng} / \mathrm{ml}) ; \operatorname{LPS}(10,25,50$, $100 \mu \mathrm{g} / \mathrm{ml})$; EGCG $(10,25,50,100 \mu \mathrm{M})$ without and with PMA; doxycycline $(10,25,50,100 \mu \mathrm{M})$ without and with PMA; NM $(10,50,100,500,1000 \mu \mathrm{g} / \mathrm{ml})$ without and with PMA; retinoic acid $(50 \mu \mathrm{M})$; dexamethasone $(50 \mu \mathrm{M})$; actinomycin-D (2 and $4 \mu \mathrm{g} / \mathrm{ml})$; and cyclohexamide ( 2 and $4 \mu \mathrm{g} / \mathrm{ml})$. The plates were then returned the to the incubator. The conditioned medium from each treatment was collected separately, pooled, and centrifuged at $4^{\circ} \mathrm{C}$ for $10 \mathrm{~min}$ at $3,000 \mathrm{rpm}$ to remove cells and cell debris. The clear supernatant was collected and used for gelatinase zymography, as described below.

Gelatinase zymography. Gelatinase zymography was utilized because of its high sensitivity for gelatinolytic enzymatic activity and ability to detect both pro- and active-forms of
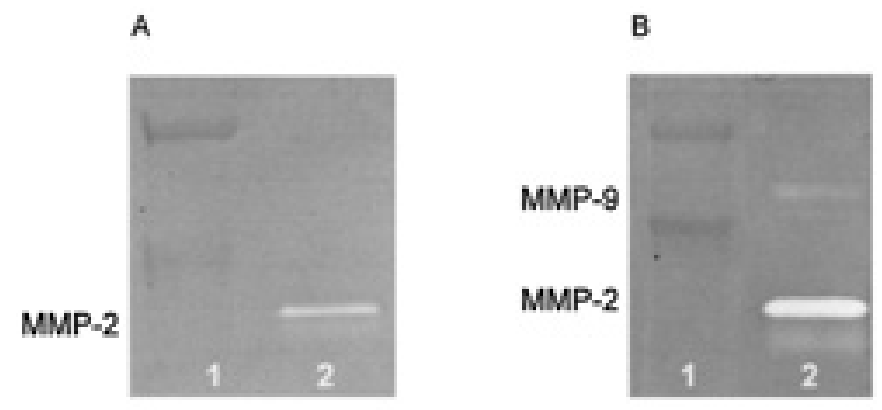

Legend: 1-Markers, 2-Controlno treatment

Figure 1. Expression of MMPs in LC and MM cell in untreated media. (A) Gelatinase zymogram of lung cancer cell line A-549 expressing only one band of molecular weight $72 \mathrm{kDa}$ corresponding to MMP-2. (Legend: 1Markers, 2-Control/no treatment). (B) Gelatinase zymogram of mesothelioma cell line MSTO-211H showing strong expression of a $72-\mathrm{kDa}$ band corresponding to MMP-2, and a faint band of molecular weight $97 \mathrm{kDa}$ corresponding to MMP-9.

MMP-2 and MMP-9. Upon renaturation of the enzyme, the gelatinases digest the gelatin in the gel and give clear bands in an intensely stained background. Gelatinase zymography was performed in $10 \%$ Novex pre-cast SDS polyacrylamide gel in the presence of $0.1 \%$ gelatin under non-reducing conditions. Culture media $(20 \mu 1)$ were mixed with sample buffer and loaded for SDS-PAGE with Tris glycine SDS buffer, as suggested by the manufacturer (Novex). Samples were not boiled before electrophoresis. Following electrophoresis the gels were washed twice in $2.5 \%$ Triton X-100 for $30 \mathrm{~min}$ at room temperature to remove SDS. The gels were then incubated at $37^{\circ} \mathrm{C}$ overnight in substrate buffer containing $50 \mathrm{mM}$ Tris- $\mathrm{HCl}$ and $10 \mathrm{mM} \mathrm{CaCl}_{2}$ at $\mathrm{pH} 8.0$ and stained with $0.5 \%$ Coomassie Blue R250 in 50\% methanol and $10 \%$ glacial acetic acid for $30 \mathrm{~min}$ and destained. Protein standards were run concurrently and approximate molecular weights were determined by plotting the relative mobilities of known proteins. Gelatinase zymograms were scanned using CanoScan 9950F Canon scanner at 300 dpi. The intensity of the bands was evaluated using the pixel-based densitometer program Un-Scan-It, Version 5.1, 32-bit, by Silk Scientific Corp. (P.O. Box 533, Orem, UT, USA), at a resolution of 1 Scanner Unit (1/100 of an inch for an image that was scanned at $100 \mathrm{dpi}$ ).

\section{Results}

MMP-2 and MMP-9 expression in untreated LC and MM cell lines. LC cells were found to express MMP-2, whereas MM cells were found to express a light band corresponding to MMP-9 (MW $97 \mathrm{kDa}$ ) in addition to MMP-2, as shown in Fig. 1 .

Effect of inducers PMA, TNF- $\alpha, I L-1 \beta$ and LPS on MMP-2 and MMP-9 in LC and MM cell lines. Table I shows the quantitative densitometry results from the effects of inducers PMA, TNF- $\alpha$, IL- $1 \beta$ and LPS on MMP-2 and MMP-9 expression in LC and MM. Figs. 2A and 3A show gelatinase zymograms of MMP-2 and MMP-9 expression in PMA (0$100 \mathrm{ng} / \mathrm{ml}$ )-stimulated LC and MM cells, respectively, and 
Table I. Effect of inducers on MMP-2 and MMP-9 expression in lung cancer A-549 and mesothelioma MSTO-211 cell lines .

\begin{tabular}{lcccc}
\hline & \multicolumn{2}{c}{ Lung (A-549) } & \multicolumn{2}{c}{ Mesothelioma (MSTO-211H) } \\
\cline { 2 - 3 } & MMP-2 (\%) & MMP-9 (\%) & MMP-2 (\%) & MMP-9 (\%) \\
\hline PMA (ng/ml) & & & 25.3 & 0.5 \\
Control & 11.2 & 0 & 17.6 & 1.0 \\
10 & 15.4 & 0 & 17.8 & 1.5 \\
25 & 16.0 & 0 & 15.3 & 5.7 \\
50 & 16.4 & 12.0 & 13.2 & 2.1 \\
100 & 16.6 & 12.4 & & 0.2 \\
TNF- $\alpha(\mathrm{ng} / \mathrm{ml})$ & & & 25.1 & 0.3 \\
Control & 5.7 & 0 & 19.1 & 0.3 \\
0.1 & 12.4 & 0 & 17.0 & 0.2 \\
1 & 25.5 & 0 & 18.7 & 0.3 \\
10 & 27.3 & 0 & & 0.3 \\
25 & 29.1 & 0 & 24.7 & 0.2 \\
IL-13 (ng/ml) & & & 20.5 & 0.2 \\
Control & 21.3 & 0 & 20.1 & 0.3 \\
0.1 & 12.9 & 0 & 18.1 & 0.3 \\
1 & 22.3 & 0 & 15.3 & \\
10 & 24.7 & 0 & & 0.2 \\
25 & 18.8 & 0 & 27.5 & 0.2 \\
LPS $(\mu \mathrm{g} / \mathrm{ml})$ & & & 16.7 & 0.3 \\
Control & 12.7 & 0 & 17.0 & 0.2 \\
10 & 18.5 & 0 & 19.7 & 0.2 \\
25 & 19.8 & 0 & & \\
50 & 21.4 & 0 & & \\
100 & 27.6 & & & \\
\hline
\end{tabular}

Figs. 2B and 3B the respective graphs of the MMP expression as determined by densitometric analysis of their gelatinase zymograms. As shown in Fig. 2A, LC cells expressed only one band of molecular weight corresponding to MMP-2 (72 kDa) in unstimulated cultures. In contrast, MM cells expressed two bands, a major MMP-2 band and a faint band corresponding to the molecular weight of MMP-9 $(92 \mathrm{kDa})$, as seen in Fig. 3A. PMA had a moderate dose-dependent (10, $25,50,100 \mathrm{ng} / \mathrm{ml}$ ) stimulatory effect on MMP-2 expression in LC cells, and a significant stimulatory effect on MMP-9 expression at high concentrations (50 and $100 \mathrm{ng} / \mathrm{ml}$ ). In contrast, PMA had a gradual dose-dependent inhibitory effect on MMP-2 expression in MM cells, while a stimulatory dosedependent effect on MMP-9 expression. TNF- $\alpha$ showed a stimulatory dose-dependent effect on MMP-2 expression in LC cells, and a moderate inhibitory effect on MMP-2 in MM cells. IL-1ß had a stimulatory effect on MMP-2 in LC cells up to $10 \mathrm{ng} / \mathrm{ml}$ concentration, and an inhibitory effect at $25 \mathrm{ng} / \mathrm{ml}$. In the MM cell line, IL-1ß had a dose-dependent inhibitory effect on MMP-2. TNF- $\alpha$ and IL-1ß did not stimulate MMP-9 secretion in either cancer cell line. Finally, LPS up-regulated the expression of MMP-2 in a dose-dependent manner in LC cells, whereas it had a dose-dependent inhibitory effect in MM cells. LPS, as with TNF- $\alpha$ and IL-1ß,

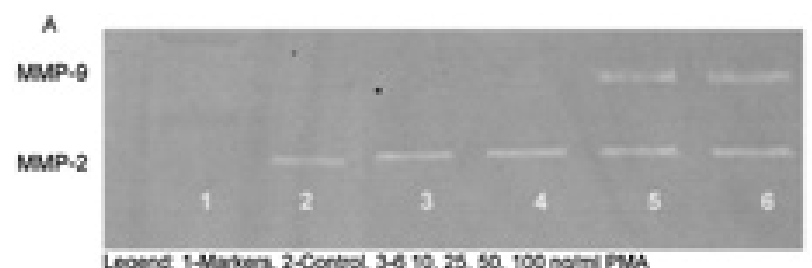

8

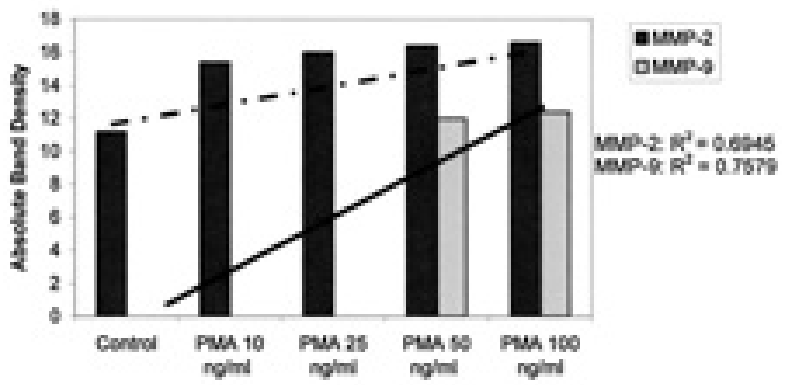

Figure 2. Effect of PMA on LC cell line A-549 as an example of the effects of inducers on LC. (A) Gelatinase zymogram of LC cells treated with PMA shows a dose-dependent increase in both MMP-2 and MMP-9. (Legend: 1-Markers, 2-Control, 3-6 PMA 10, 25, 50, 100 ng/ml). (B) Densitometric analysis of the gelatinase zymogram showing band density as a percentage of the sum of all band densities in the zymogram. Trend analysis: MMP-2, $\mathrm{R}^{2}=0.6945 ;$ MMP-9, $\mathrm{R}^{2}=0.7579$. 


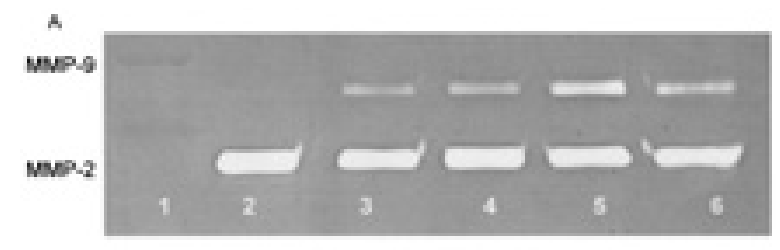

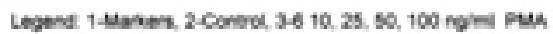

B

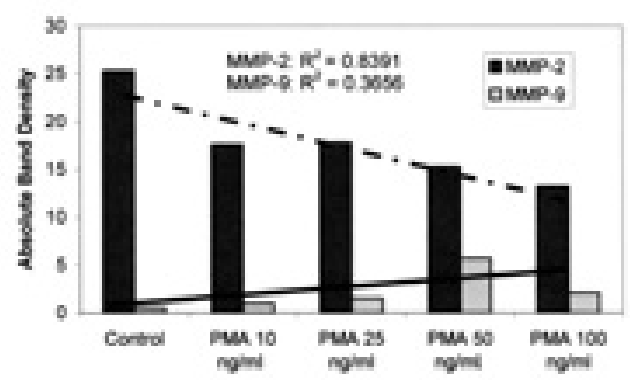

Figure 3. Effect of PMA on MM cell line MSTO-211H as an example of the effects of inducers on MM. (A) Gelatinase zymogram of MM cells treated with PMA shows a dose-dependent increase in MMP-9 and a dosedependent decrease in MMP-2. (Legend: 1-Markers, 2-Control, 3-6 PMA $10,25,50,100 \mathrm{ng} / \mathrm{ml}$ ). (B) Densitometric analysis of the gelatinase zymogram showing band density as a percentage of the sum of all band densities in the zymogram. Trend analysis: MMP-2, $\mathrm{R}^{2}=0.8391$; MMP-9, $\mathrm{R}^{2}=0.3656$. had no effect on MMP-9 expression in either cancer cell line.

Effect of inhibitors doxycycline and EGCG on MMP-2 and $M M P-9$ expression in LC and MM cell lines. The effect of doxycycline and EGCG on MMP-2 and MMP-9 expression in LC and MM cells was investigated through the use of PMA. As shown in Table II, quantitative densitometric analyses of gelatinase zymograms show a dose-dependent decrease in MMP-2 expression in LC and MM cells treated with either doxycycline or EGCG. When both cell lines were stimulated with PMA to express MMP-9, both MMP-2 and MMP-9 expression decreased in a dose-dependent manner with either doxycycline or EGCG treatment. In both uninduced and induced media, LC cells were more sensitive to EGCG and doxycycline than MM cells. Zymograms and respective densitometric graphs of MMP-2 and MMP-9 expression in doxycycline-treated LC cells without PMA are shown in Fig. 4 and with PMA in Fig. 6. Zymograms and respective densitometric graphs of MMP-2 and MMP-9 expression in doxycycline-treated MM cells without PMA are shown in Fig. 5 and with PMA in Fig. 7.

Table II. Effect of inhibitors doxycycline and EGCG with and without PMA treatment on lung cancer A-549 and mesothelioma MSTO-211H cell lines.

\begin{tabular}{|c|c|c|c|c|}
\hline & \multicolumn{2}{|c|}{ Lung (A-549) } & \multicolumn{2}{|c|}{ Mesothelioma (MSTO-211H) } \\
\hline & MMP-2 (\%) & MMP-9 (\%) & MMP-2 (\%) & MMP-9 (\%) \\
\hline \multicolumn{5}{|c|}{ Doxycycline $(\mu \mathrm{M})$} \\
\hline Control & 20.5 & 0 & 19.8 & 0.3 \\
\hline 10 & 34.3 & 0 & 25.3 & 0.2 \\
\hline 25 & 24.6 & 0 & 26.6 & 0.1 \\
\hline 50 & 18.7 & 0 & 19.9 & 0.1 \\
\hline 100 & 1.9 & 0 & 8.4 & 0 \\
\hline \multicolumn{5}{|c|}{ Doxycycline $(\mu \mathrm{M})$ with } \\
\hline \multicolumn{5}{|c|}{ PMA $(100 \mathrm{ng} / \mathrm{ml})$} \\
\hline Control & 31.5 & 14.5 & 30.3 & 3.7 \\
\hline 10 & 22.1 & 3.1 & 19.0 & 0.4 \\
\hline 25 & 16.0 & 3.3 & 23.3 & 0.6 \\
\hline 50 & 8.1 & 1.0 & 15.6 & 0.1 \\
\hline 100 & 0.3 & 0.1 & 7.0 & 0.0 \\
\hline \multicolumn{5}{|c|}{ EGCG $(\mu \mathrm{g} / \mathrm{ml})$} \\
\hline Control & 39.5 & 0 & 30.7 & 0.3 \\
\hline 10 & 19.0 & 0 & 34.1 & 0.3 \\
\hline 25 & 12.9 & 0 & 30.7 & 0.2 \\
\hline 50 & 16.7 & 0 & 3.5 & 0 \\
\hline 100 & 11.9 & 0 & 0.2 & 0 \\
\hline \multicolumn{5}{|c|}{ EGCG $(\mu \mathrm{g} / \mathrm{ml})$ with } \\
\hline \multicolumn{5}{|c|}{ PMA (100 ng/ml) } \\
\hline Control & 33.1 & 28.4 & 20.0 & 3.0 \\
\hline 10 & 9.8 & 5.3 & 21.0 & 9.0 \\
\hline 25 & 4.1 & 2.4 & 24.0 & 7.0 \\
\hline 50 & 5.6 & 5.8 & 7.0 & 8.0 \\
\hline 100 & 2.2 & 3.3 & 0.4 & 0.6 \\
\hline
\end{tabular}


A

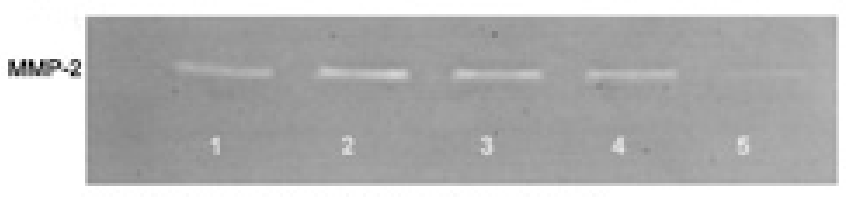

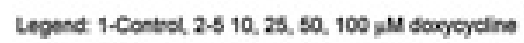

B

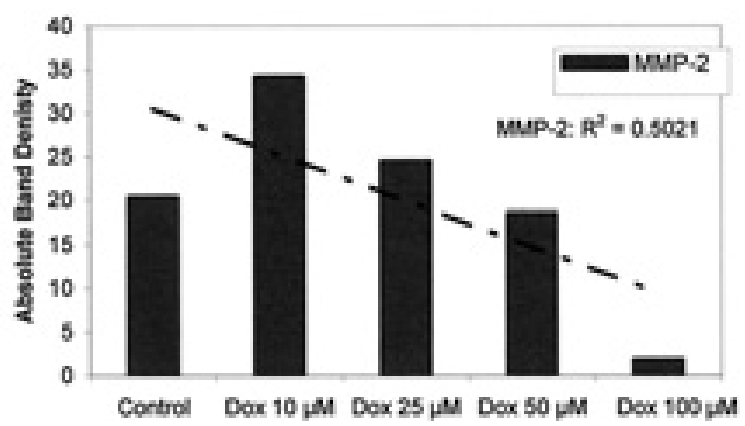

Figure 4. Effect of doxycycline on LC cell line A-549 as an example of the effects of inhibitors on LC. (A) Gelatinase zymogram of LC cells treated with doxycycline (Dox) shows a dose-dependent decrease in MMP-2. (Legend: 1-Control, 2-5 doxycycline 10, 25, 50, $100 \mu \mathrm{M}$ ). (B) Densitometric analysis of the gelatinase zymogram showing band density as a percentage of the sum of all band densities in the zymogram. Trend analysis: MMP-2, $\mathrm{R}^{2}=0.5021$.

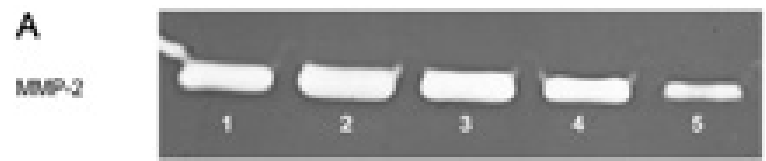

8

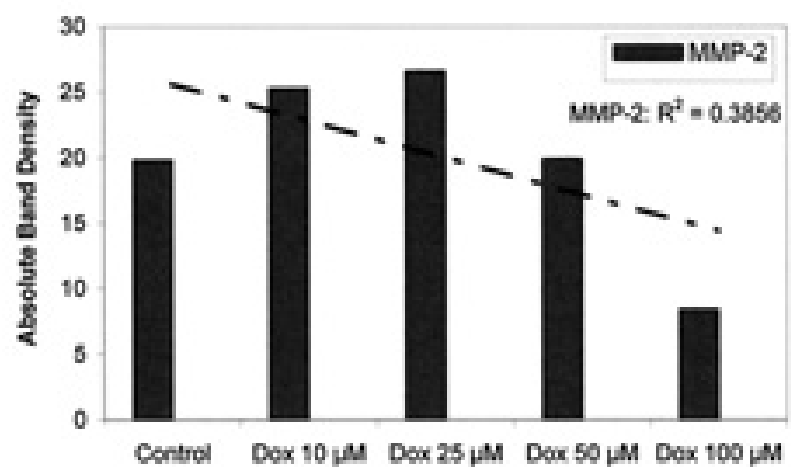

Figure 5. Effect of doxycycline on MM cell line MSTO-211H as an example of the effects of inhibitors on MM. (A) Gelatinase zymogram of MM cells treated with doxycycline (Dox) shows a dose-dependent decrease in MMP-2. (Legend: 1-Control, 2-5 doxycycline 10, 25, 50, $100 \mu \mathrm{M}$ ). (B) Densitometric analysis of the gelatinase zymogram showing band density as a percentage of the sum of all band densities in the zymogram. Trend analysis: MMP-2, $\mathrm{R}^{2}=0.3843$.

Effect of inhibitors retinoic acid, dexamethasone, actinomycin-D, and cyclohexamide on MMP-2 and MMP-9 expression in $L C$ and $M M$ cell lines. As shown in Table III, the expression of MMP-2 was significantly inhibited by dexamethasone $(50 \mu \mathrm{M})$ and retinoic acid $(50 \mu \mathrm{M})$ in both LC and MM cell lines. Actinomycin-D significantly decreased

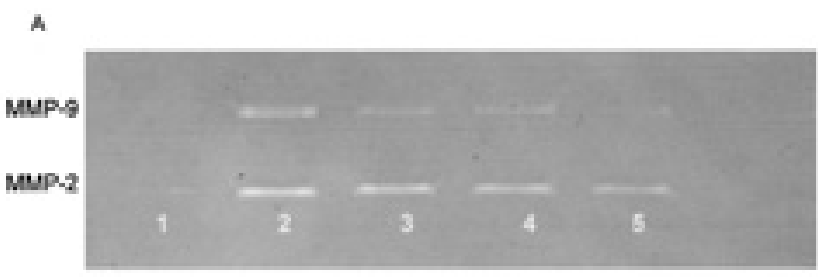

Legand: 1-Control.2-5 10, 25, 50, 100 , M dexycycline

B

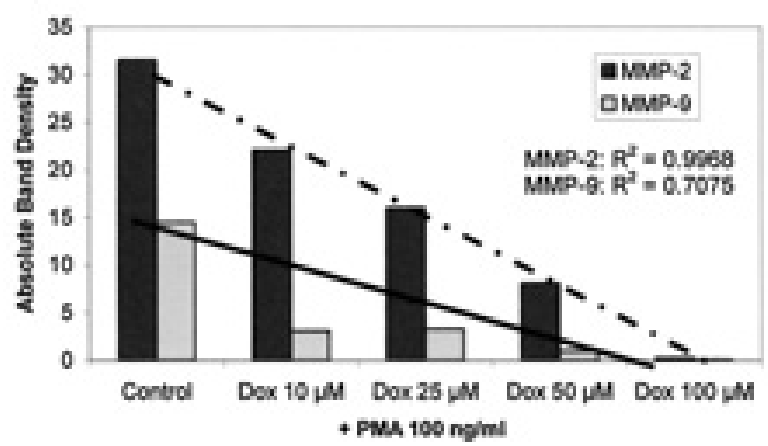

Figure 6. Effect of doxycycline and PMA on LC cell line A-549 as an example of the effects of inhibitors on MMP-2 and MMP-9 expression in LC. (A) Gelatinase zymogram of LC cells treated with doxycycline (Dox) and PMA (100 ng/ml) shows a dose-dependent decrease in both MMP-2 and MMP-9. (Legend: 1-Control, 2-5 doxycycline 10, 25, 50, $100 \mu \mathrm{M}$ ). (B) Densitometric analysis of the gelatinase zymogram showing band density as a percentage of the sum of all band densities in the zymogram. Trend analysis: MMP-2, $\mathrm{R}^{2}=0.9968 ;$ MMP-9, $\mathrm{R}^{2}=0.7075$.

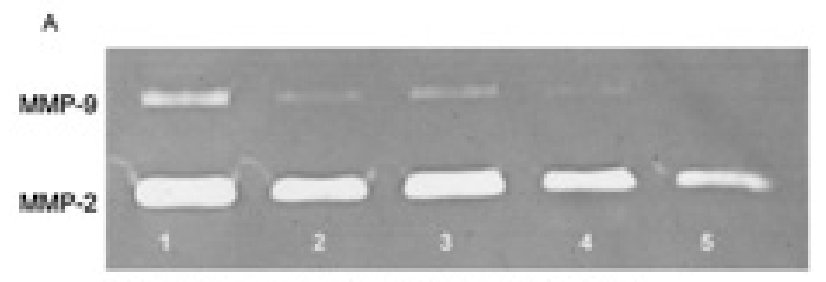

Legend: 1-Control. 2-5 10, 25, 50, 100, M dexyencline

B

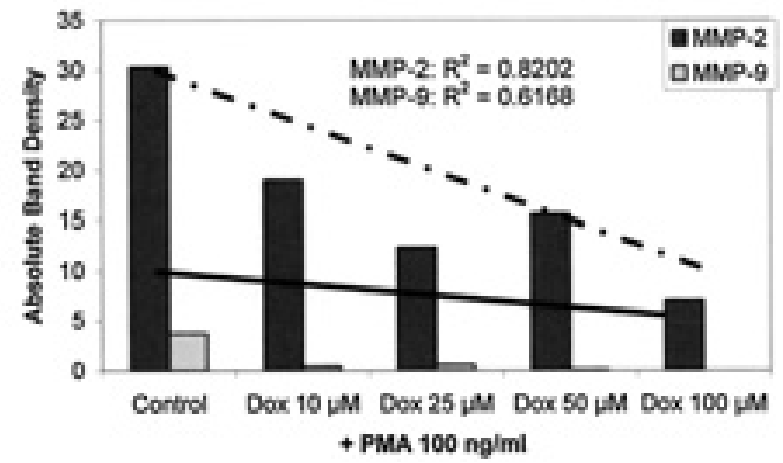

Figure 7. Effect of doxycycline and PMA on MM cell line MSTO-211H as an example of the effects of inhibitors on MMP-2 and MMP-9 expression in MM. (A) Gelatinase zymogram of MM cells treated with doxycycline (Dox) and PMA $(100 \mathrm{ng} / \mathrm{ml})$ shows a dose-dependent decrease in MMP-2 and MMP-9. (Legend: 1-Control, 2-5 doxycycline 10, 25, 50, $100 \mu \mathrm{M}$ ). (B) Densitometric analysis of the gelatinase zymogram showing band density as a percentage of the sum of all band densities in the zymogram. Trend analysis: MMP-2, $\mathrm{R}^{2}=0.8202 ;$ MMP-9, $\mathrm{R}^{2}=0.6168$.

the expression of MMP-2 in both cell lines in a dose-dependent manner. In contrast, cyclohexamide significantly decreased 
Table III. Effect of inhibitors dexamethasone, actinomycin-D, cyclohexamide and retinoic acid on MMP-2 and MMP-9 expression in lung cancer A-549 and mesothelioma MSTO-211H cell lines.

\begin{tabular}{|c|c|c|c|c|}
\hline & \multicolumn{2}{|c|}{ Lung (A-549) } & \multicolumn{2}{|c|}{ Mesothelioma (MSTO-211H) } \\
\hline & MMP-2 (\%) & MMP-9 (\%) & MMP-2 (\%) & MMP-9 (\%) \\
\hline \multicolumn{5}{|c|}{ Dexamethasone $(\mu \mathrm{M})$} \\
\hline Control & 84.4 & 0 & 64.6 & 0.3 \\
\hline 50 & 15.6 & 0 & 35.1 & 0 \\
\hline \multicolumn{5}{|c|}{ Actinomycin-D $(\mu \mathrm{g} / \mathrm{ml})$} \\
\hline Control & 62.3 & 0 & 85.8 & 0.1 \\
\hline 2 & 23.1 & 0 & 10.0 & 0 \\
\hline 4 & 14.6 & 0 & 4.1 & 0 \\
\hline \multicolumn{5}{|c|}{ Cyclohexamide $(\mu \mathrm{g} / \mathrm{ml})$} \\
\hline Control & 100 & 0 & 92 & 0.1 \\
\hline 2 & 0 & 0 & 5.3 & 0 \\
\hline 4 & 0 & 0 & 2.6 & 0 \\
\hline \multicolumn{5}{|c|}{ Retinoic acid $(\mu \mathrm{M})$} \\
\hline Control & 96.3 & 0 & 96.3 & 0.1 \\
\hline 50 & 3.7 & 0 & 3.6 & 0 \\
\hline
\end{tabular}

Table IV. Effect of the nutrient mixture with and without PMA on MMP-2 and MMP-9 expression in lung cancer A-549 and mesothelioma MSTO-211H cell lines.

\begin{tabular}{|c|c|c|c|c|}
\hline & \multicolumn{2}{|c|}{ Lung (A-549) } & \multicolumn{2}{|c|}{ Mesothelioma (MSTO-211H) } \\
\hline & MMP-2 (\%) & MMP-9 (\%) & MMP-2 (\%) & MMP-9 (\%) \\
\hline \multicolumn{5}{|c|}{ Nutrient mixture $(\mu \mathrm{g} / \mathrm{ml})$} \\
\hline Control & 46.8 & 0 & 22.5 & 0.6 \\
\hline 10 & 40.8 & 0 & 25.0 & 0.5 \\
\hline 50 & 9.6 & 0 & 27.8 & 0.4 \\
\hline 100 & 2.8 & 0 & 22.4 & 0.2 \\
\hline 500 & 0 & 0 & 0.5 & 0 \\
\hline 1000 & 0 & 0 & 0.1 & 0 \\
\hline \multicolumn{5}{|c|}{$\begin{array}{l}\text { Nutrient mixture }(\mu \mathrm{g} / \mathrm{ml}) \\
\text { with PMA }(100 \mathrm{ng} / \mathrm{ml})\end{array}$} \\
\hline Control & 8.1 & 36.4 & 13.4 & 14.5 \\
\hline 10 & 4.9 & 41.7 & 16.4 & 15.8 \\
\hline 50 & 1.0 & 5.0 & 12.7 & 14.5 \\
\hline 100 & 0.2 & 0.6 & 6.8 & 5.9 \\
\hline 500 & 0 & 0 & 0 & 0 \\
\hline 1000 & 0 & 0 & 0 & 0 \\
\hline
\end{tabular}

MMP-2 expression in a dose-dependent manner in MM cells, whereas it completely blocked MMP-2 expression in the LC cell line (at 2 and $4 \mu \mathrm{g} / \mathrm{ml}$ ).

Effect of the nutrient mixture (NM) on MMP-2 and MMP-9 expression in $L C$ and $M M$ cell lines. The effect of the nutrient mixture on expression of MMP-2 and MMP-9 was also investigated in LC and MM cell lines, without and with
PMA, as shown in Table IV and Figs. 8-11. NM had a dosedependent decrease in MMP-2 expression in unstimulated LC cells (Fig. 8), and a dose-dependent decrease in MMP-2 and MMP-9 expression in unstimulated MM cells (Fig. 9). In PMA-stimulated LC (Fig. 10) and MM (Fig. 11), both MMP-2 and MMP-9 were decreased in a dose-dependent fashion by the nutrient mixture. The NM was much more effective in LC compared to MM. 


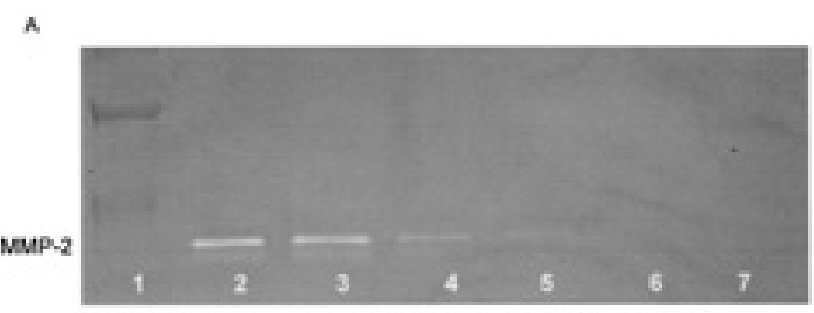

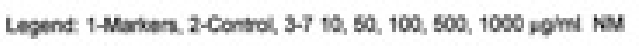

B

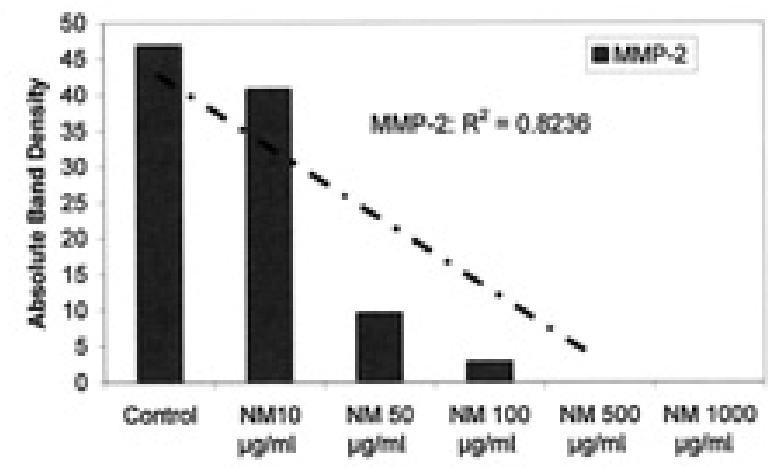

Figure 8. Effect of nutrient mixture in LC cell line A-549. (A) Gelatinase zymogram of LC cells treated with nutrient mixture shows a dose-dependent decrease in MMP-2 expression. (Legend: 1-Markers, 2-Control, 3-7 NM 10, $50,100,500,1000 \mu \mathrm{g} / \mathrm{ml}$ ). (B) Densitometric analysis of the gelatinase zymogram showing band density as a percentage of the sum of all band densities in the zymogram. Trend analysis: MMP- $2, \mathrm{R}^{2}=0.8236$.

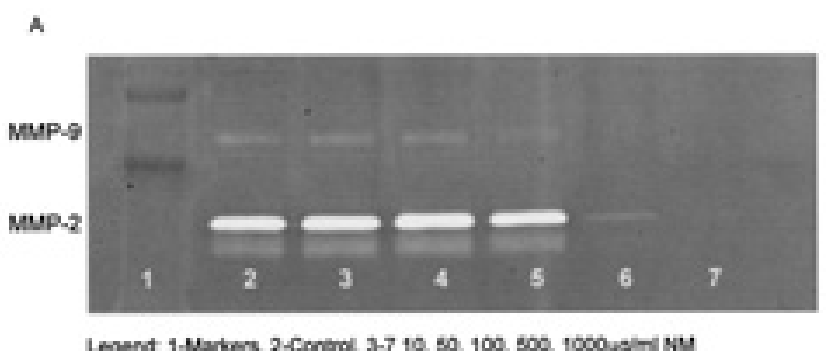

B

Legend: 1-Markens, 2-Contol, 3-7 19,50,109,500, 1000pg/mi NM

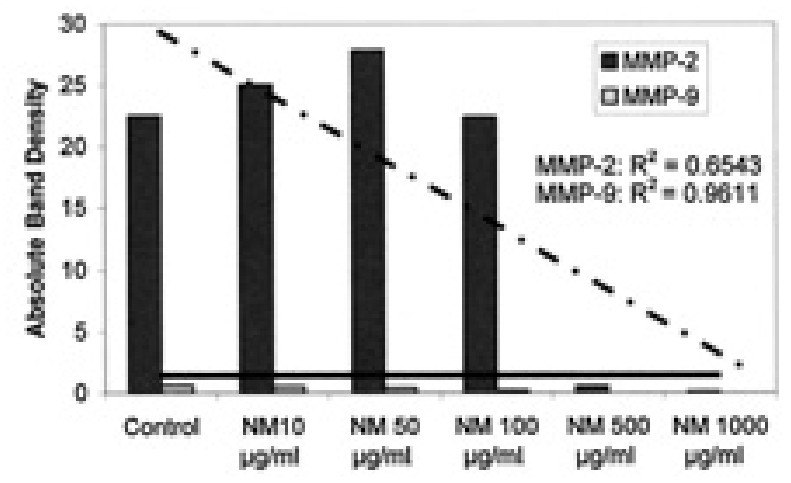

Figure 9. Effect of nutrient mixture on MM cell line MSTO-211H. (A) Gelatinase zymogram of MM cells treated with nutrient mixture shows a dose-dependent decrease in both MMP-2 and MMP-9 expression. (Legend: 1-Markers, 2-Control, 3-7 NM 10, 50, 100, 500, $1000 \mu \mathrm{g} / \mathrm{ml}$ ). (B) Densitometric analysis of the gelatinase zymogram showing band density as a percentage of the sum of all band densities in the zymogram. Trend analysis: MMP-2, $\mathrm{R}^{2}=0.6543$; MMP-9, $\mathrm{R}^{2}=0.9611$.

\section{Discussion}

MMPs play a crucial role in tumor invasion and metastasis to distant organs. Experimental and clinical studies have shown

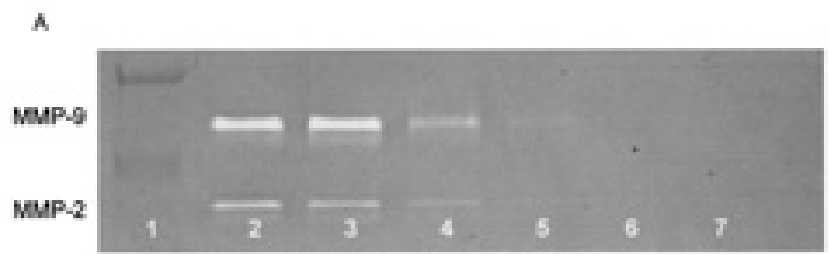

Legend: 1-Marken, 2-Conted 3-7 10, 50, 100, 500, 1000 poimt hal

B

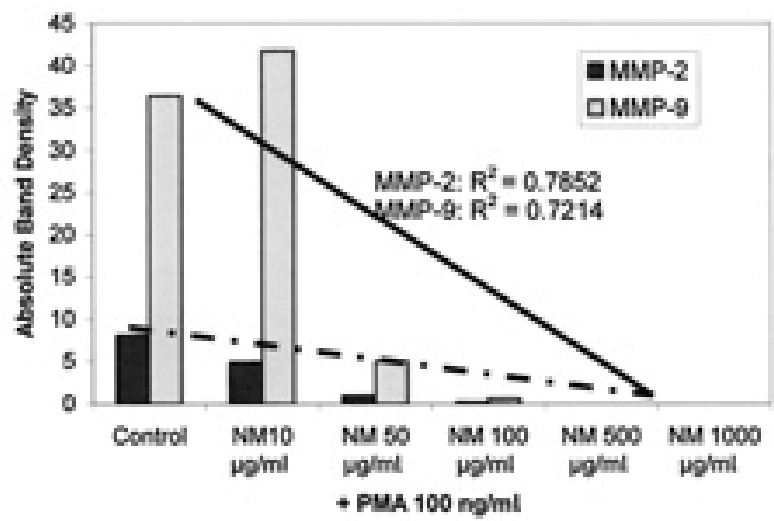

Figure 10. Effect of nutrient mixture and PMA in LC cell line A-549. (A) Gelatinase zymogram of the effect of NM on PMA-treated $(100 \mathrm{ng} / \mathrm{ml})$ LC cells shows a dose-dependent decrease in MMP-2 expression. (Legend: 1-Markers, 2-Control, 3-7 NM 10, 50, 100, 500, $1000 \mu \mathrm{g} / \mathrm{ml})$. (B) Densitometric analysis of the gelatinase zymogram showing band density as a percentage of the sum of all band densities in the zymogram. Trend analysis: MMP-2, $\mathrm{R}^{2}=0.7852 ;$ MMP-9, $\mathrm{R}^{2}=0.7214$.

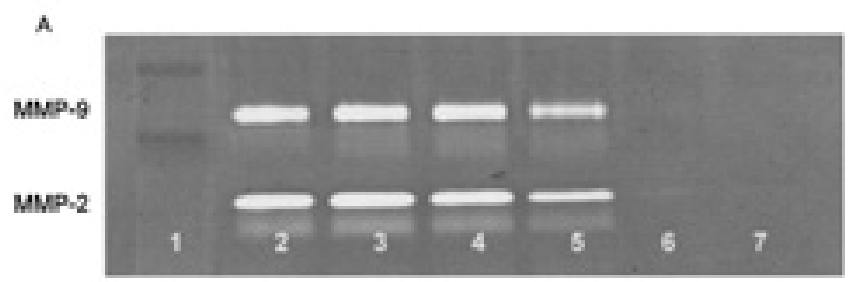

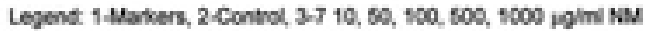

B

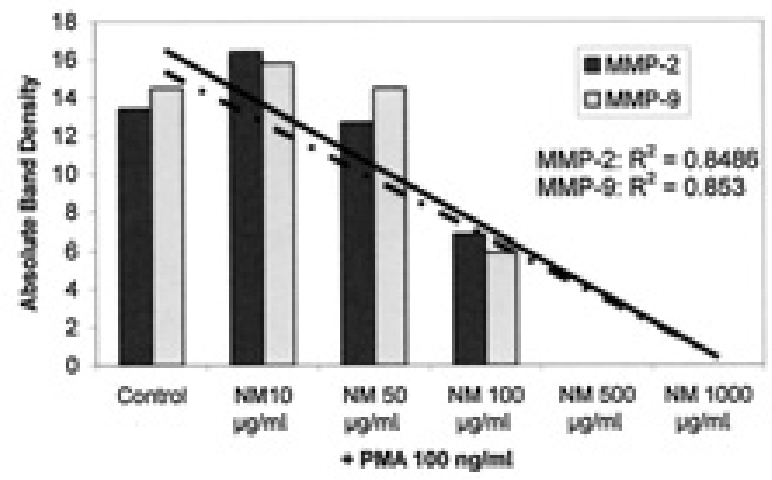

Figure 11. Effect of nutrient mixture and PMA on MM cell line MSTO211H. (A) Gelatinase zymogram of the effect of NM on PMA-treated (100 ng/ $\mathrm{ml}$ ) MM cells shows a dose-dependent decrease in both MMP-2 and MMP-9 expression. (Legend: 1-Markers, 2-Control, 3-7 NM 10, 50, 100, 500, $1000 \mu \mathrm{g}$ / $\mathrm{ml}$ ). (B) Densitometric analysis of the gelatinase zymogram showing band density as a percentage of the sum of all band densities in the zymogram. Trend analysis: MMP-2, $\mathrm{R}^{2}=0.8492 ;$ MMP- $9, \mathrm{R}^{2}=0.8523$.

a correlation between increased MMPs and tumor progression and metastasis (5-10). Thus, knowledge of MMP regulation 
is of great importance for developing therapeutic strategies. MMP expression is regulated at both pre- and post-transcriptional levels. A number of extracellular factors, including cytokines, growth factors, cell contact with ECM, and inducers and inhibitors, have been implicated in the regulation of MMP expression in different types of tumor cells $(25,26)$.

In this study, we examined MMP secretion patterns in two related cancer cell lines, LC and MM, stimulated by cytokines, PMA and LPS. In addition, we investigated the effect of inhibitors doxycycline and EGCG and others, such as dexamethasone, retinoic acid and agents that affect transcription and translation levels, such as actinomycin-D and cyclohexamide. Furthermore, we tested a nutrient mixture and found it to have inhibitory effects on MMP-2 and MMP-9 expression.

Our results demonstrate an up- and down-regulatory effect of cytokines, mitogens and inhibitors on MMP-2 and MMP-9 expression in LC and MM cells. Normal LC cells expressed only MMP-2, whereas MM cells expressed both MMP-2 and MMP-9, but MMP-9 to a much smaller extent than MMP-2. These results are in agreement with earlier reports $(13,22)$. TNF- $\alpha$, IL-1ß, LPS and PMA, had an up-regulatory effect on the expression of MMP-2 in a dose-dependent fashion in LC. In contrast, these agents had an opposite effect in MM, showing down-regulation of MMP-2 with increasing concentration. The induction of MMP-9 by PMA was more pronounced in MM than LC. The inhibitors doxycycline and EGCG showed a similar pattern of inhibition on MMP-2 and MMP-9 expression, both without and with PMA. However, EGCG was a more effective inhibitor than doxycycline in LC. LC cells were also more sensitive to doxycycline than were MM cells, whereas retinoic acid exhibited the same degree of MMP-2 and MMP-9 inhibition for both cell lines. LC cells and MM cells reacted differently towards actinomycin-D and cyclohexamide. LC was more sensitive to cyclohexamide, with abolished activity of both MMP-2 and MMP-9 at $2 \mu \mathrm{g} /$ $\mathrm{ml}$, whereas MMP-2 and MMP-9 expression in MM cells was not totally blocked but greatly reduced. Actinomycin-D was more effective in LC than MM. The differential effects of actinomycin-D and cyclohexamide on LC and MM may be due to actinomycin-D and cyclohexamide having effects at different cellular levels, transcriptional and translational, respectively.

Despite the extensive use of conventional therapies, cancer mortality has not decreased over the last few decades and is increasing. Standard cancer treatment generally involves a combination of surgery, multiple chemotherapeutic agents, and radiation therapy. In a study of 453 patients being treated at MD Anderson Cancer Center between 1997 and 1998, approximately $80 \%$ of patients sought complementary/alternative therapies, including vitamins and herbs (63\%), in addition to spiritual practices and physical therapies (26). The nutrition mixture studied, which contains lysine, proline, ascorbic acid and green tea extract among other micronutrients, has been shown to have anti-tumor and anti-invasive potential in in vitro and in vivo studies $(27,28)$. In this study, the nutrition mixture without and with PMA showed a dosedependent decrease of MMP-2 and MMP-9 in both cancer cell lines. The nutrient mixture was more effective in inhibiting MMP expression in LC than in MM cell line.
The nutrient mixture was designed by defining critical physiological targets in cancer progression and metastasis, such as ECM integrity and MMP activity. Optimal ECM formation and structure is dependent upon adequate supplies of ascorbic acid, lysine and proline, which ensure proper synthesis and hydroxylation of collagen fibers. Manganese and copper are also essential for collagen formation. Lysine, a natural inhibitor of plasmin-induced proteolysis, plays an important role in ECM stability $(29,30)$. Green tea extract has been shown to control cancer cell growth, metastasis, angiogenesis and other aspects of cancer progression (31-35). Nacetyl cysteine has been observed to inhibit MMP-9 activity (36) and invasive activities of tumor cells (37). Selenium has been shown to interfere with MMP secretion and tumor invasion (38), as well as migration of endothelial cells through ECM (37). In addition to addressing ECM properties, some nutrients are critical in inducing cancer cell death. A recent study confirmed that ascorbic acid inhibits cell division and growth through production of hydrogen peroxide (39). Since arginine is a precursor of nitric oxide (NO), any deficiency of arginine can limit the production of $\mathrm{NO}$, which has been shown to predominantly act as an inducer of apoptosis, as in breast cancer cells (40).

In conclusion, our results indicate that cytokines, PMA, LPS, inhibitors and NM have differential up- and downregulatory effects in MMP expression in LC and MM, and suggest their clinical use as therapeutic strategies in the management of LC and MM and pathogenesis of these diseases.

\section{References}

1. CDC Lung Cancer: Statistics http://www.cdc.gov/cancer/lung/ statistics/Accessed 3/25/09).

2. Hart JA: Mesothelioma (Malignant); http://www.nlm.nih.gov/ medlineplus/ency/article/000115.htm, 2004.

3. Antman KH: Clinical presentation and natural history of benign and malignant mesothelioma. Semin Oncol 8: 313-320, 1981.

4. Fidler IJ: Molecular biology of cancer: invasion and metastasis. In: Cancer: Principles and Practice of Oncology. 5th edition. De Vita VT, Hellman S and Rosenberg SA (eds). LippincottRaven, Philadelphia, PA, pp135-152, 1997.

5. Liotta LA, Tryggvason K, Garbisa A, Hart I, Foltz CM and Shafie S: Metastatic potential correlates with enzymatic degradation of basement membrane collagen. Nature 284: 67-68, 1980.

6. Stetler-Stevenson WG: The role of matrix metalloproteinases in tumor invasion, metastasis and angiogenesis. Surg Oncol Clin N Am 10: 383-392, 2001.

7. Cottam DW, Rennie IG, Woods K, Parsons MA, Bunning RA and Rees RC: Gelatinolytic metalloproteinase secretion patterns in ocular melanoma. Invest Ophthalmol Vis Sci 32: 1923-1927, 1992.

8. Fishman DA, Bafetti L, Banionis S, Kearns AS, Chilukuri K and Stack MS: Production of extracellular matrix degrading proteinases by primary cultures of human epithelial ovarian carcinoma cells. Cancer 80: 1457-1463, 1997.

9. Garzetti G, Ciavattini A, Lucarini G, Goteri G, De Nicolis M, Garbisa S, Masiero L, Romanini C and Graziella B: Tissue and serum metalloproteinase (MMP-2) expression in advanced ovarian serous cytstadenocarcinomas: clinical and prognostic implications. Anticancer Res 15: 2799-2804, 1995.

10. Gohji K, Fujomoto N, Hara I, Fujii A, Gotoh A, Okada H, Arakawa S, Kitazawa S, Miyake H, Kamidono S and Nakijima M: Serum matrix metalloproteinase- 2 and its density in men with prostate cancer as a new predictor of disease extension. Int $\mathbf{J}$ Cancer 79: 96-101, 1998.

11. Hirano H, Tsugu M, Kizaki T, Sashikata T, Yoshi Y, Okada Y and Mori H: Expression of matrix metalloproteinases, tissue inhibitors of metalloproteinase, collagens and ki67 antigen in pleural malignant mesothelioma: an immunohistochemical and electron microscopic study. Med Electron Microsc 35: 16-23, 2002. 
12. Edwards JC, McLaren J, Jones JL, Walker DA and O'Byrne KJ: Matrix metalloproteinases 2 and 9 (gelatinases A and B) expression in malignant mesothelioma and benign pleura. Br J Cancer 88: 1553-1559, 2003.

13. Schültz A, Schneidenbach D, Aust G, Tannpfel A, Steinert M and Wittekind C: Differential expression and activity status of MMP-1, MMP-2 and MMP-9 in tumor and stromal cells of squamous cell carcinomas of the lung. Tumor Biol 23: 179-184, 2002.

14. Takashi M, Kazumitsu O, Kazuo K, Yoshio N, Fuji N, Mamou K, Motohiko F, Nanao N and Yukiyasy S: Analysis of circulating plasma matrix metalloproteinases (MMP) and tissue inhibitors of MMP in lung cancer patients. J Nihon Univ Med Assoc 59: 97-102, 2000.

15. Stetler-Stevenson WG: Type IV collagenases in tumor invasion and metastasis. Cancer Metastasis Rev 9: 289-303, 1990.

16. Bérubé M, Deschambeault A, Boucher M, Germain L, Petitclerc E and Guérin SL: MMP-2 expression in uveal melanoma: differential activation status dictated by the cellular environment. Mol Vis 11: 1101-1111, 2005.

17. Sato T, Sakai T, Noguchi Y, Takta M, Hirakawa S and Ito A: Tumor-stromal cell contact promotes invasion of human uterine cervical carcinoma cells by augmenting the expression and activation of stromal matrix metalloproteinases. Gynecol Oncol 92: 47-56, 2004.

18. Di Nezza LA, Misajon A, Zhang J, Jobling T, Quinn MA, Ostör AG, Nie G, Lopata A and Salamonsen LA: Presence of active gelatinases in endometrial carcinoma and correlation of matrix metalloproteinase expression with increasing tumor grade and invasion. Cancer 94: 1466-1475, 2002.

19. Liotta LA and Kohn EC: The microenvironment of the tumorhost interface. Nature 411: 375-379, 2001.

20. Pyke C, Kristensen P, Ralfkiaer E, Gröndahl-Hansen J, Eriksen J, Blasi $\mathrm{F}$ and Danø K: Urokinase-type plasminogen activator is expressed in stromal cells and its receptor in cancer cells at invasive foci in human colon adenocarcinomas. Am J Pathol 138: 1059-1067, 1991

21. Harvey P, Clark IM, Jourand MC, Warn RM and Edwards DR: Hepatocyte growth factor/scatter factor enhances the invasion of mesothelioma cell lines and the expression of matrix metalloproteinases. Br J Cancer 83: 1147-1153, 2000.

22. Liu Z, Ivanoff A, Klominek J: Expression and activity of matrix metalloproteases in human malignant mesothelioma cell lines. Int J Cancer 91: 638-643, 2001.

23. Vincenti MP, White LA, Schroen DJ, et al: Regulating expression of the gene for matrix metalloproteinase-1 (collagenase): mechanisms that control enzyme activity, transcription and mRNA stability. Crit Rev Eukaryot Gene Expr 6: 391-411, 1996.

24. Ray JM and Stetler-Stevenson WG: The role of matrix metalloproteinase and their inhibitors in tumour invasion, metastasis and angiogenesis. Eur Respir J 7: 2062-2072, 1994.

25. Apodaca G, Rutka JT, Bouhana K, Berens ME, Giblin JR, Rosenblum ML, McKerrow JH and Banda MJ: Expression of metalloproteinases and metalloproteinase inhibitors by fetal astrocytes and glioma cells. Cancer Res 50: 2322-2329, 1990.
26. Richardson MA, Sanders T, Palmer JL, Greisinger A and Singletary SE: Complementary/alternative medicine use in a comprehensive cancer center and the implications for oncology. J Clin Oncol 18: 2505-2514, 2000.

27. Roomi MW, Ivanov V, Kalinovsky T, Niedzwiecki A and Rath M: Inhibition of pulmonary metastasis of melanoma B16FO cells in C57BL/6 mice by a nutrient mixture consisting of ascorbic acid, lysine, proline, arginine, and green tea extract. Exp Lung Res 32: 517-530, 2006.

28. Roomi MW, Kalinovsky T, Roomi NW, Ivanov V, Rath M and Niedzwiecki A: Suppression of growth and hepatic metastasis of murine B16FO melanoma cells by a novel nutrient mixture. Oncol Rep 20: 809-817, 2008.

29. Rath M and Pauling L: Plasmin-induced proteolysis and the role of apoprotein(a), lysine and synthetic analogs. Orthomolecular Med 7: 17-23, 1992.

30. Sun Z, Chen YH, Wang P, Zhang J, Gurewich V, Zhang P and Liu JN: The blockage of high-affinity lysine binding sites of plasminogen by EACA significantly inhibits prourokinaseinduced plasminogen activation. Biochem Biophys Acta 1596: 182-192, 2002.

31. Valcic S, Timmermann BN, Alberts DS, Wachter GA, Krutzsch M, Wymer J and Guillen JM: Inhibitory effect of six green tea catechins and caffeine on the growth of four selected human tumor cell lines. Anticancer Drugs 7: 461-468, 1996.

32. Mukhtar H and Ahmed N: Tea polyphenols: prevention of cancer and optimizing health. AM J Clin Nutr 71: S1698-S1702, 2000.

33. Yang GY, Liao J, Kim K, Yurtow EJ and Yang CS: Inhibition of growth and induction of apoptosis in human cancer cell lines by tea polyphenols. Carcinogenesis 19: 611-616, 1998

34. Taniguchi S, Fujiki H, Kobayashi H, Go H, Miyado K, Sadano H and Shimikawa R: Effect of (-) epigallocatechin gallate, the main constituent of green tea, on lung metastasis with mouse B16 melanoma cell lines. Cancer Lett 65: 51-54, 1992.

35. Hare Y: Green Tea: Health Benefits and Applications. Marcel Dekker, Basel, New York, 2001

36. Kawakami S, Kageyama Y, Fujii Y, Kihara K and Oshima H: Inhibitory effects of N-acetylcysteine on invasion and MMP-9 production of T24 human bladder cancer cells. Anticancer Res 21: 213-219, 2001.

37. Morini M, Cai T, Aluigi MG, Noonan DM, Masiello L, De Floro S, D'Agostinin F, Albini A and Fassima G: The role of the thiol N-acetyl cysteine in the prevention of tumor invasion and angiogenesis. Int J Biol Markers 14: 268-271, 1999.

38. Yoon SO, Kim MM and Chung AS: Inhibitory effects of selenite on invasion of HT 1080 tumor cells. J Biol Chem 276: 20085-20092, 2001

39. Maramag C, Menon M, Balaji KC, Reddy PG and Laxmanan S: Effect of vitamin $C$ on prostate cancer cells in vitro: effect on cell number, viability and DNA synthesis. Prostate 32 : 188-195, 1997.

40. Cooke JP and Dzau VJ: Nitric oxide synthase: role in the genesis of vascular disease. Annu Rev Med 48: 489-509, 1997. 